c) 2022 Maria José Sá and Sandro Serpa. This is an open access article licensed under the Creative Commons Attribution-NonCommercial 4.o International License (https://creativecommons.org/licenses/by-nc/4.o/)

\title{
Social Sciences and Inequalities in the New Post-COVID-19 "Normal"
}

\author{
Maria José Sá \\ CIPES -Centre for Research in Higher Education Policies, \\ 4450-227 Matosinhos, Portugal \\ Sandro Serpa \\ Faculty of Social and Human Sciences, \\ Department of Sociology, University of the Azores; \\ Interdisciplinary Centre of Social Sciences \\ CICS.UAc/CICS.NOVA. UAc; \\ Interdisciplinary Centre for Childhood and Adolescence \\ NICA - UAc, the Azores, Portugal
}

DOI: https://doi.org/10.36941/jesr-2022-0oo1

\section{Abstract}

The pandemic caused by COVID-19 (either through its direct effects by the disease it causes or the measures taken in an attempt to control its spread) had, and still has, a profound effect at several levels beyond the medical, such as the economic and social, political, scientific, psychological, educational, legal and religious levels, among others. However, studies demonstrate that this influence has not been the same for all due to old inequalities and also the emergence of new inequalities. In this letter to the Editor, the authors discuss some of the contributions of the Social Sciences to the understanding of social inequalities in this new postCOVID-19 "normal" through the mobilization of relevant literature and also their experience in analysing COVID-19 with the eyes of the Social Sciences, notwithstanding their plurality. The results of this analysis allow concluding that the Social Sciences can make a very relevant contribution - in an interdisciplinary way - to the understanding of this phenomenon of the relationship between COVID-19 and inequalities based on socioeconomic factors with the aim of increasing social cohesion and social justice.

Keywords: Social Sciences, COVID-19 pandemic, inequalities, intergenerational inequalities, equality of opportunity, new normal, socioeconomic factors, social cohesion

\section{Introduction}

The world has fully realized the extreme change caused by the measures to combat the COVID-19 pandemic (caused by the Severe Acute Respiratory Syndrome Coronavirus SARS-CoV-2), such as social distancing, social isolation, quarantine, lockdown, closures, and now vaccination. This array of measures has caused profound and multiple implications in various areas, namely the social, economic, political, health, scientific, psychological, educational, legal, religious, and digitalization of society, among others (British Academy, 2021; Clark, 2021; Farooq, 2020; Aristovnik, Ravšelj, \& Umek, 2020; Silva, 2020; Ferreira, 2021; Neves \& Sobral, 2021; Cheng, Pellegrini, Zhou, \& Cheung, 2020; Quan, 
2020). These actions potentially affect vulnerable populations, according to their different contexts and characteristics (Rudnick, 2020; Cheng et al., 2020; Peralta, Carvalho, \& Esteves, 2021; Mamede \& Adão e Silva, 2021), as well as social cohesion itself (Jewett, Mah, Nicholas, \& Larsen, 2021; Banki, 2021; Sonekar \& Ponnaiah, 2020).

In this context, both old and new inequalities, in several dimensions, have been enhanced (British Academy, 2021; Medeiros, 2021; Ferreira \& Serpa, 2020, 2021), which generates profound challenges (Ferreira \& Serpa, 2020; Flecha, 2020).

All this motivated this paper to the Editor, whose purpose is to offer an insight on the contributions of the Social Sciences' role in the apprehension of social inequalities in this new postCOVID-19 "normal".

\section{COVID-19, Social Sciences and Inequalities}

\subsection{Intergenerational inequalities and COVID-19}

The COVID-9 pandemic was envisaged, in practice, as a kind of monopoly of the health sciences (Zhang \& Huang, 2021; Aristovnik et al., 2020). However, the relevance of the Social Sciences in studying and understanding these pandemic processes is acknowledged by several authors (Bardosh et al., 2020; Aristovnik et al., 2020; Ferreira \& Serpa, 2020, 2021). The Social Sciences, as a form of specific scientific knowledge in their theoretical and methodological plurality, analyse a "holistic engagement with social, cultural, historical, economic and political factors as they affect, and are affected by, disease outbreaks, epidemics and pandemics" (Bardosh et al., 2020, p. 3). Thus, it is a relevant component in the understanding of the pandemic, inasmuch that social behaviours are closely related to collective representations (Feierstein, 2021).

It follows that, as a social process, pandemics do not exert the same influence on all social groups (Feierstein, 2021; Medeiros, 2021). For example, on vaccination, Kos and Tašner (2021) found in their study that the worries about the COVID-19 vaccine, on the one hand, and, on the other hand, the feeling that it was paramount to take it were closely linked to the individuals' political stances, as well as to demographic factors. The most reluctant individuals were politically conservative and had low fear of COVID-19. These individuals were mostly female, had low academic qualifications, pertained to younger age groups, had lower income and, in terms of ethnicity, were non-white.

The COVID-19 pandemic raises profound challenges also in terms of its consequences, which potentially shape old but also new social inequalities, such as health, social class, gender, race, ethnicity, education, disability, social exclusion and poverty, stigmatization, and the growing digitalization of societies (Reiss, 2020; Silva, 2020; British Academy, 2021; Serpa \& Ferreira, 2021; Ferreira \& Serpa, 2020; Gugushvili, 2021; Rimmer, 2020; Pearson \& Reddy, 2021; Ali, Asaria, \& Stranges, 2020; Mamede \& Adão e Silva, 2021). These inequalities caused by COVID-19, already labelled as an "inequality virus" (Berkhout et al., 2021), are felt in specific aspects, such as scientific production, with clear gender inequalities, insofar that women publish significantly less than men compared to what happened before the pandemic (MacArthur, Cox, Egan, \& Komer, 2020).

For example, in the articulation between education and the acceleration of digitalization in society and, consequently, also in education, through - among several other elements - online teaching (Science Insights Education Frontiers, 2020; Cheng et al., 2020), there is an unquestionable inequality in terms of the access to electronic instruments with Internet access and/or the competence to use them (Sá \& Serpa, 2018, 2020, 2021; Silva \& Gomes Filho, 2020; Cheng et al., 2020), which foster digital divides (Burke, 2020).

In short, the COVID-19 pandemic not only made existing inequalities more visible but also amplified them and created new inequalities, essentially in the most vulnerable groups in the social hierarchy (Carmo, Tavares, \& Cândido, 2020; Acuña Ortigoza, 2021; Thomeer, Yahirun, \& ColónLópez, 2020; Warren \& Bordoloi, 2020; Aguilar-Palacio et al., 2021; Ali et al., 2020; Wang et al., 2020; Stok, Bal, Yerkes, \& de Wit, 2021; Gugushvili, 2021). 
There are several examples, whether articulated or not, of intergenerational inequalities that are reproduced over time and have been enhanced by the COVID-19 pandemic (Carmo et al., 2020; Stok et al., 2021; O'Keefe et al., 2021; Cheshmehzangi, 2021), in a sort of vicious cycle, fostering the creation, within the same social groups, of new inequalities, such as the institutionalization of racism, sexism and the gender divide (Gugushvili, 2021; Farquharson \& Thornton, 2020; Warren \& Bordoloi, 2020; Wang et al., 2020; Lazonick, Moss, \& Weitz, 2021; Bann et al., 2021; Pereira, Pedro, Mendes, Duarte, \& Silva, 2021), ethnicity and disability (Burke, 2020; Katikireddi et al., 2021). This is the case of the studies on BAME (Black, Asian, and Minority Ethnicity) and social class (Burke, 2020), immigrants and disabilities (Warren \& Bordoloi, 2020), ageism (Warren \& Bordoloi, 2020), which often intersect with each other in a socio-historical perpetuation (Wang et al., 2020; Warren \& Bordoloi, 2020), with profound influences on the individual's potential future social and economic path. There are several reasons for these social inequalities in the impact of COVID-19, depicted in Table 1.

Table 1: Schematic overview of reasons for social inequalities in the impact of COVID-19

\begin{tabular}{|c|c|}
\hline Reason for inequality & Brief explanation \\
\hline $\begin{array}{l}\text { Pre-existing health } \\
\text { conditions }\end{array}$ & $\begin{array}{l}\text { Underprivileged communities in socioeconomic terms and from racial and ethnic } \\
\text { minorities are more prone to having pre-existing chronic health conditions, which } \\
\text { entail a higher risk of morbidity and mortality associated with COVID-19 by these } \\
\text { groups. }\end{array}$ \\
\hline $\begin{array}{l}\text { Fewer opportunities for } \\
\text { supporting the immune } \\
\text { system }\end{array}$ & $\begin{array}{l}\text { Underprivileged communities in socioeconomic terms and from racial and ethnic } \\
\text { minorities normally have few opportunities to rest, exercise, have healthy meals, and } \\
\text { avoid and deal with stress. These conditions stimulate the immune system and can } \\
\text { help mitigate the effects of COVID-19. }\end{array}$ \\
\hline Lower health literacy & $\begin{array}{l}\text { Underprivileged communities in socioeconomic terms and from racial and ethnic } \\
\text { minorities usually have lower health literacy, which makes them more unprotected } \\
\text { from misinformation and less oriented towards following the measures of prevention } \\
\text { and protection. }\end{array}$ \\
\hline $\begin{array}{l}\text { Access to suboptimal } \\
\text { health care }\end{array}$ & $\begin{array}{l}\text { nderprivileged communities in socioeconomic terms and from racial and ethnic } \\
\text { inorities more frequently have poor-quality health care insurance and access to } \\
\text { ealth care and, consequently, more frequently receive insufficient health care. }\end{array}$ \\
\hline $\begin{array}{l}\text { Less opportunity to } \\
\text { follow preventive and } \\
\text { protective measures }\end{array}$ & $\begin{array}{l}\text { Underprivileged communities in socioeconomic terms and from racial and ethnic } \\
\text { minorities have increased difficulties in working from home, keeping social distance } \\
\text { in the workplace, self-isolating and complying with prevention measures. }\end{array}$ \\
\hline
\end{tabular}

Source: Adapted from Stok et al. (2021, p. 3)

Without being deterministic or fatalistic, all these inequalities also hinder the implementation of mitigation and control measures for this pandemic on the part of some of these communities (Raitano, 2015). Katikireddi et al. (2021) offer six suggestions of measures to be implemented, which consist of "(1) differential exposure to the virus; (2) differential vulnerability to infection/disease; (3) differential health consequences of the disease; (4) differential social consequences of the disease; (5) differential effectiveness of pandemic control measures and (6) differential adverse consequences of control measures" (p. 1).

These processes of intergenerational inequality transmission, which are shaped by the COVID19 pandemic and affect, in particular, the most vulnerable individuals (Raitano, 2015; Gugushvili, 2021), can call into question social cohesion itself (Burke, 2020).

From all the above, there is an "inequality pandemic" (Attanasio \& Rajan, 2020, p. 1), which reinforces social inequalities by affecting individuals in situations of greater vulnerability (Firmino da Costa, 2020; Tavares \& Cândido, 2020). 


\subsection{Social Sciences and COVID-19 social inequalities}

In a very pertinent study by the British Academy (2021), titled "The COVID decade: Understanding the long-term societal impacts of COVID-19", it is possible to find several challenges to address. The study puts forth a set of seven policy goals to shape a COVID decade, depicted in Table 2.

Table 2: Seven policy goals to shape a COVID decade

\begin{tabular}{|c|c|}
\hline 1. & $\begin{array}{l}\text { Build multi-level governance structures based on empowering participation, engagement and } \\
\text { cooperation to strengthen the capacity to identify and respond to local needs. }\end{array}$ \\
\hline 2. & $\begin{array}{l}\text { Improve the way we develop, share and communicate knowledge, data and information to enable all } \\
\text { decision-makers to work from shared understanding of the facts. }\end{array}$ \\
\hline 3. & $\begin{array}{l}\text { Prioritize investment in digital infrastructure as a critical public service to eliminate the digital divide, } \\
\text { improve communication and joint problem solving, and create a more equitable basis for education } \\
\text { and employment. }\end{array}$ \\
\hline 4. & Reimagine urban spaces to support sustainable and adaptable local businesses, amenities and lifestyles. \\
\hline 5. & $\begin{array}{l}\text { Create a more agile, responsive education and training system capable of meeting the needs of a new } \\
\text { social and economic environment and acting as a catalyst to develop and enhance our future. }\end{array}$ \\
\hline 6. & $\begin{array}{l}\text { Strengthen and expand community-led social infrastructure that underpins the vital services and } \\
\text { support structures needed to enhance local resilience, particularly in the most deprived areas. }\end{array}$ \\
\hline 7 . & $\begin{array}{l}\text { Empower a range of actors, including business and civil society, to work together with a sense of social } \\
\text { purpose to help drive a solid strategy for recovery across the economy and society. }\end{array}$ \\
\hline
\end{tabular}

Source: Adapted from the British Academy (2021, pp. 7-9)

These "Seven policy goals to shape a COVID decade" can only be successfully addressed if there is a systemic analysis. According to the British Academy (2021), it is and will be paramount to bring together different types of knowledge, in particular the knowledge from the Human and Social Sciences, as societies overcome the health crisis but have to address the social, economic and cultural impacts brought about by the pandemic.

\section{Conclusion}

The analysis that substantiates this letter to the Editor allows concluding that the contribution of the Social Sciences to the understanding of social inequalities in this new post-COVID-19 "normal" is pivotal (Silva, 2020; Farooq, 2020; Bardosh et al., 2020; Nasir et al., 2020; Wang et al., 2020; Flecha, 2020), in a logic of interdisciplinarity among several scientific areas (Lehmann et al., 2021; Reiss, 2020; Firmino da Costa, 2020; Tavares \& Cândido, 2020).

This is both a need and an opportunity for the Social Sciences to show their usefulness in the dimension of the implementation and social impact for complex problems. It seems extremely pertinent to consider the words of Nisa and Belanger (2021) when the authors sustain that the Social and Behavioral Sciences may have missed an opportunity brought about by the pandemic caused by the SARS-CoV-2 virus. Indeed, if there had been the coordination of efforts between these sciences to objectively and concretely guide the implementation of preventive health behaviours on a global scale, the merits of the Social Sciences would have been more evident.

\section{References}

Acuña Ortigoza, M. (2021). América latina. Entre la nueva realidad y las viejas desigualdades [Latin America. Between the new reality and the old inequalities]. Telos Revista de Estudios Interdisciplinarios en Ciencias Sociales, 23(1), 129-140. https://doi.org/10.36390/telos231.10 
Aguilar-Palacio, I., Maldonado, L., Malo, S., Sánchez-Recio, R., Marcos-Campos, I., Magallón-Botaya, R., \& Rabanaque, M. J. (2021). COVID-19 inequalities: Individual and area socioeconomic factors (Aragón, Spain). International Journal of Environmental Research and Public Health, 18(12), 6607. https://doi.org/10.339o/ijerph18126607

Ali, S., Asaria, M., \& Stranges, S. (2020). COVID-19 and inequality: Are we all in this together? Canadian Journal of Public Health, 111(3), 415-416. https://doi.org/10.17269/s41997-020-00351-0

Aristovnik, A., Ravšelj, D., \& Umek, L. (2020). A bibliometric analysis of COVID-19 across science and social science research landscape. Sustainability, 12(21), 9132. https://doi.org/10.3390/su12219132

Attanasio, O., \& Rajan, R. (2020). The invisible COVID-19 graveyard: Intergenerational losses for the poorest young people and actions to address a human development pandemic. United Nations Development Programme.

https://www.latinamerica.undp.org/content/rblac/en/home/library/crisis_prevention_and_recovery/theinvisible-covid-19-graveyard--intergenerational-losses-for-t.html

Banki, S. R. (2021). "Learning alone-a with Corona": Two challenges and four principles of tertiary teaching. Journal of Research in Innovative Teaching E Learning, 14(1), 65-74. https://doi.org/10.1108/jrit-12-2020-0o81

Bann, D., Villadsen, A., Maddock, J., Hughes, A., Ploubidis, G. B., Silverwood, R., \& Patalay, P. (2021). Changes in the behavioural determinants of health during the COVID-19 pandemic: Gender, socioeconomic and ethnic inequalities in five British cohort studies. Journal of Epidemiology and Community Health, 2020-215664. https://doi.org/10.1136/jech-2020-215664

Bardosh, K. L., de Vries, D. H., Abramowitz, S., Thorlie, A., Cremers, L., Kinsman, J., \& Stellmach, D. (2020). Integrating the social sciences in epidemic preparedness and response: A strategic framework to strengthen capacities and improve global health security. Globalization and Health, 16(1). https://doi.org/10.1186/s12992020-00652-6

Berkhout, E., Galasso, N., Lawson, M., Rivero Morales, P.A., Taneja, A., \& Vázquez Pimentel, D. A. (2021). The inequality virus. Oxford: Oxfam International.

British Academy (2021). Shaping the COVID decade: Addressing the long-term societal impacts of COVID-19. London: The British Academy. https://doi.org/10.5871/bac19stf/9780856726590.001

Burke, S. (2020). Stronger together? Intergenerational connection and Covid-19. Quality in Ageing and Older Adults, 21(4), 253-259. https://doi.org/10.1108/qaoa-07-2020-0033

Cark, K. (2021). Why our brains may need time to adjust to a world without social distancing. https://www.weforum.org/agenda/2021/o6/neuroscience-brain-social-distancingeffects?utm_source=facebook\&utm_medium=social_scheduler\&utm_term=COVID19\&utm_content=30\%2Fo6\%2F2021\%2014\%3A15\&fbclid=IwARobzmntX1BtX42BFBPYrGQjDtjahAzJrQ3QaQJ Heb_A7IYdx-NqRpY7nQs. Accessed on July 1, 2021.

Carmo, R. M., Tavares, I., \& Cândido, A. F. (Eds.) (2020). Um olhar sociológico sobre a crise Covid-19 em livro [A sociological look at the Covid-19 crisis in a book]. Lisboa: Observatório das Desigualdades. https://doi.org/10.15847/ciesod2020covid19

Cheng, X., Pellegrini, M., Zhou, L., \& Cheung, A. C. K. (2020). Not only survival but stronger: The impact of alarming invader of SARS-CoV-2 on global education. Science Insights Education Frontiers, 7(2), 835-86o. https://doi.org/10.15354/sief.20.oro61

Cheshmehzangi, A. (2021). Vulnerability of the UK's BAME communities during COVID-19: The review of public health and socio-economic inequalities. Journal of Human Behavior in the Social Environment, 1-18. https://doi.org/10.1080/10911359.2021.1875949

Farooq, M. (2020). Emerging research areas in social sciences due to Covid-19. Global Journal of Emerging Sciences, 2(1), 1-4. https://doi.org/10.37187/gjoes.0320.0201.01

Farquharson, W. H., \& Thornton, C. J. (2020). Debate: Exposing the most serious infirmity - racism's impact on health in the era of COVID-19. Child and Adolescent Mental Health, 25(3), $182-183$. https://doi.org/10.1111/camh.12407

Feierstein, D. (2021). Las pandemias son fenómenos sociológicos [Pandemics are sociological phenomena]. Actualizaciones en Sida e Infectología, 104, 96-97. https://doi.org/10.52226/revista.v28i104.66

Ferreira C. M., \& Serpa S. (2020). COVID-19 and social sciences. Societies, 10(4), 1-3. https://doi.org/10.339o/soc10040100

Ferreira, C. M., \& Serpa, S. (Eds.) (2021). COVID-19 and social Sciences. MDPI: Basel, Switzerland. ISBN 978-30365-0154-3; eISBN 978-3-0365-0155-o. https://doi.org/10.339o/books978-3-0365-0155-o 
Ferreira, J. M. (2021). Virtual e digital à luz da teoria sociológica e filosófica contemporânea [Virtual and digital in light of the contemporary sociological and philosophical theory]. Logeion: Filosofia da Informação, 7(2), 5971. https://doi.org/10.21728/logeion.2021v7n2.p59-71

Flecha, R. (2020). Contributions from social theory to sustainability for all. Sustainability, $12(23)$, 9949. https://doi.org/10.3390/su12239949

Firmino da Costa, A. (2020). Desigualdades sociais e pandemia. In R. M. Carmo, I. Tavares, \& A. F. Cândido (Eds.), Um olhar sociológico sobre a crise Covid-19 em livro [A sociological look at the Covid-19 crisis in a book] (pp. 4-15). https://doi.org/10.15847/ciesod2020covid19

Gugushvili, A. (2021). Equality of opportunity and health in post-COVID world. Public Health in Practice, $2,100135$. https://doi.org/10.1016/j.puhip.2021.100135

Jewett, R. L., Mah, S. M., Nicholas, H., \& Larsen, M. M. (2021). Social cohesion and community resilience during COVID-19 and pandemics: A rapid scoping review to inform the United Nations research roadmap for COVID-19 recovery. International Journal of Health Services, 51(3), $325-336$. http://dx.doi.org/10.1177/0020731421997092

Katikireddi, S. V., Lal, S., Carrol, E. D., Niedzwiedz, C. L., Khunti, K., Dundas, R., ... Barr, B. (2021). Unequal impact of the COVID-19 crisis on minority ethnic groups: A framework for understanding and addressing inequalities. Journal of Epidemiology and Community Health, 2020-216061. https://doi.org/10.1136/jech-2020-216061

Kos, Ž., \& Tašner, V. (2021). Demanding relations: Sociological imagination, education, the usefulness of concepts and the world around us. Educar, 57(1), 261-274. https://doi.org/10.339o/vaccines9040339

Lazonick, W., Moss, P., \& Weitz, J. (2021). Employment mobility and the belated emergence of the black middle class. Institute for New Economic Thinking Working Paper Series, 1-6o. https://doi.org/10.36687/inetwp143

Lehmann, P., Beck, S., de Brito, M. M., Gawel, E., Groß, M., Haase, A., ... Thrän, D. (2021). Environmental sustainability post-COVID-19: Scrutinizing popular hypotheses from a social science perspective. Sustainability, 13(16), 8679. https://doi.org/10.339o/su13168679

MacArthur, K. R., Cox, M. J., Egan, C., \& Komer, L. (2020). Pre-existing social conditions: A call to prevent the perpetuation of gender inequalities in research production during COVID-19. International Journal of Medical Students, 8(3), 217-219. https://doi.org/10.5195/ijms.2020.875

Mamede, R. P., \& Adão e Silva, P. (2021). O estado da nação e as políticas públicas 2021: Governar em estado de emergência [The state of the nation and public policies 2021: Governing in a state of emergency]. Lisboa: IPPS (Instituto para as Políticas Públicas e Sociais) - ISCTE — Instituto Universitário de Lisboa. ISBN 978-989-8990-03-7.

Medeiros, R. S. (2021). A pandemia e as nossas desigualdades duradouras [The pandemic and our enduring inequalities]. CAOS - Revista Eletrônica de Ciências Sociais, 1(26), $320-362$. https://doi.org/10.46906/caos.n26.57370.p320-362

Nasir, A., Shaukat, K., Hameed, I. A., Luo, S., Alam, T. M., \& Iqbal, F. (2020). A bibliometric analysis of Corona pandemic in social sciences: A review of influential aspects and conceptual structure. IEEE Access, 8, 133377133402. https://doi.org/10.1109/access.2020.3008733

Neves, F. M., \& Sobral, F. A. (2021). A resposta da política científica e tecnológica à pandemia da COVID-19 [The response of the science and technology policy in the COVID-19 crisis]. Revista Brasileira de Sociologia - RBS, 9(21), 55-77. https://doi.org/10.20336/rbs.778

Nisa, C. F., \& Belanger, J. (2021). COVID-19 exposed why translational social science is long overdue. OSFPREPRINTS. https://doi.org/10.31219/osf.io/fgvnb

O’Keefe, V. M., Maudrie, T. L., Ingalls, A., Kee, C., Masten, K. L., Barlow, A., \& Haroz, E. E. (2021). Development and dissemination of a strengths-based indigenous children's storybook: "Our smallest warriors, our strongest medicine: Overcoming COVID-19”. Frontiers in Sociology, 6, 611356. https://doi.org/10.3389/fsoc.2021.611356

Pearson, W., \& Reddy, V. (2021). Social justice and education in the twenty-first century. Diversity and Inclusion Research, 1-10. https://doi.org/10.1007/978-3-030-65417-7_1

Pereira, H., Pedro, J., Mendes, C., Duarte, M., \& Silva, P. G. (2021). Psychosocial impacts of COVID-19 pandemic on lesbian, gay, and bisexual people living in Portugal and Brazil - A qualitative study. Journal of Psychosexual Health, 3(2), 146-159. https://doi.org/10.1177/26318318211017466

Peralta, S., Carvalho, B. P., \& Esteves, M. (2021). Portugal, Balanço Social 2020. Um retrato do país e dos efeitos da pandemia [Portugal, Social Balance 2020. A portrait of the country and the effects of the pandemic]. Lisboa: Nova School of Business and Economics.

Quan, L. (2020). Practical analysis of mental health assistance in elementary and middle schools under COVID-19 pandemic: A case study of city A in Jiangsu, China. Science Insights, 34(3), $183-193$. http://dx.doi.org/10.15354/si.20.aro26 
Raitano, M. (2015). Intergenerational transmission of inequalities in Southern European countries in comparative perspective: Evidence from EU-SILC 2011. European Journal of Social Security, 17(2), $292-314$. https://doi.org/10.1177/138826271501700208

Reiss, M. J. (2020). Science education in the light of COVID-19. Science E Education, 29(4), 1079-1092. https://doi.org/10.1007/s11191-020-00143-5

Rimmer, A. (2020). Covid-19 could widen mental health inequalities for a generation, warns charity. BMJ, m2466. https://doi.org/10.1136/bmj.m2466

Rudnick, A. (2020). Social, psychological, and philosophical reflections on pandemics and beyond. Societies, 10(2), 42. https://doi.org/10.339o/soc10020042

Sá, M. J., \& Serpa, S. (2018). Transversal competences: Their importance and learning processes by higher education students. Education Sciences, 8(3), 126, 1-12. https://doi.org/10.339o/educsci8030126

Sá, M. J., \& Serpa, S. (2020). COVID-19 and the promotion of digital competences in education. Universal Journal of Educational Research, 8(10), 4520-4528. https://doi.org/10.13189/ujer.2020.081020

Sá, M. J., \& Serpa, S. (2021). The relationship between basic education and higher education in a pandemic context: The Portuguese situation. Science Insights Education Frontiers, 8(2), $1029-1036$. https://doi.org/10.15354/sief.21.scoo2

Science Insights Education Frontiers (2020). When education faces the COVID-19 pandemic. Science Insights Education Frontiers, 5(2), I-I. https://doi.org/10.15354/sief.20.edoo4

Serpa, S., \& Ferreira, C. M. (2021). COVID-19 and stigmatisation processes. Journal of Educational and Social Research, 11(2), 5-9. https://doi.org/10.36941/jesr-2021-0025

Silva, G. O. S., \& Gomes Filho, A. D. S. (2020). Educação e tecnologia em tempos de pandemia de Covid-19 (SarsCov-2): Uma revisão da literatura na Scientific Electronic Library Online [Education and technology in pandemic times of Covid-19 (Sars-Cov-2): A literature review in the Scientific Electronic Online Library]. Revista de Psicologia, 14(53), 293-303. https://doi.org/10.14295/idonline.v14i53.2782

Silva, K. T. (2020). Opportunities and challenges for social sciences in the aftermath of the COVID-19 pandemic. Sri Lanka Journal of Social Sciences, 43(1), 1-4. https://doi.org/10.4038/sljss.v43i1.8122

Sonekar, H. B., \& Ponnaiah, M. (2020). Emergence of coronavirus (COVID-19) outbreak: Anthropological and social science perspectives. Disaster Medicine and Public Health Preparedness, 14(6), $759-761$. https://doi.org/10.1017/dmp.2020.203

Stok, F. M., Bal, M., Yerkes, M. A., \& de Wit, J. B. F. (2021). Social inequality and solidarity in times of COVID-19. International Journal of Environmental Research and Public Health, 18(12), 6339. https://doi.org/10.339o/ijerp h18126339

Tavares, I., \& Cândido, A. F. (2020). Balanço e perspetivas de futuro: O impacto da Covid-19 e a (re)produção das desigualdades sociais [Review and perspectives of future: The impact of Covid-19 and the (re)production of social inequalities]. In R. M. Carmo, I. Tavares, \& A. F. Cândido (Eds.), Um olhar sociológico sobre a crise Covid-19 em livro [A sociological look at the Covid-19 crisis in a book] (pp. 244-255). https://doi.org/10.15847/ciesod2020covid19

Thomeer, M. B., Yahirun, J., \& Colón-López, A. (2020). How families matter for health inequality during the COVID-19 pandemic. Journal of Family Theory E Review, 12(4), 448-463. https://doi.org/10.1111/jftr.12398

Wang, M. L., Behrman, P., Dulin, A., Baskin, M. L., Buscemi, J., Alcaraz, K. I., ... Fitzgibbon, M. (2020). Addressing inequities in COVID-19 morbidity and mortality: Research and policy recommendations. Translational Behavioral Medicine, 10(3), 516-519. https://doi.org/10.1093/tbm/ibaao55

Warren, M. A., \& Bordoloi, S. D. (2020). When COVID-19 exacerbates inequities: The path forward for generating wellbeing. International Journal of Wellbeing, 10(3), 1-6. https://doi.org/10.1111/jftr.12398

Zhang, T., \& Huang, X. (2021). Fighting in a parallel battlefield: Mapping the country-based scholarly landscape of social science COVID-19 publications. SSRN Electronic Journal. https://doi.org/10.2139/ssrn.3826362 